\title{
A Review: Artificial Neural Networks as Tool for Control Food Industry Process
}

\author{
Estrella Funes, Yosra Allouche, Gabriel Beltrán, Antonio Jiménez \\ IFAPA Venta del Llano (Andalusia Regional Government), Jaén, Spain \\ Email: estrellab.funes@juntadeandalucia.es
}

Received 9 February 2015; accepted 25 February 2015; published 28 February 2015

Copyright (C) 2015 by authors and Scientific Research Publishing Inc.

This work is licensed under the Creative Commons Attribution International License (CC BY). http://creativecommons.org/licenses/by/4.0/

c) (i) Open Access

\begin{abstract}
In the last year, interest in using Artificial Neural networks as a modeling tool in food technology is increasing because they have found extensive utilization in solving many complex real world problems. Due to this and as previous step at development of some project, this paper intends to introduce the reader inside neural networks: general characteristics of the ANN, their architectures, their rules of learning, types of networks and ANN's create process. Also this paper presents a comprehensive review of food industrial applications of artificial neural networks in the last year. ANN industrial applications are grouped and tabulated by their main functions and what they actually performed on the referenced papers with except the applications in the olive oil industry that are described with special emphasis.
\end{abstract}

\section{Keywords}

\section{Artificial Neural Networks, Olive Oils, Sensor On-Line, Process Control}

\section{Introduction}

In the last decades important researches in the area of artificial intelligence were developed. One of the main objectives of the science is the implementation of new technologies with capacities approaching the human being, and even better. Artificial intelligence is a powerful accomplishment in various fields, since it can supplement the human being in various activities, both easy to perform, how complex and even impossible to make as it is carrying out an activity without interruption for long periods of time and where knowledge is required.

In the search on the nature of intelligent mechanisms to try to develop machines that perform complex tasks, it is important to observe certain characteristics of human brain that can be considered crucial to the development of artificial neural networks (ANN).

Artificial neural networks are control systems necessary to solve problems in which the analytical methods 
are difficult to apply and their results have to be in a specific interval, e.g., in real time. The main objective of ANN is the development of mathematical algorithms that will enable ANNs to learn by mimicking information processing and knowledge acquisition in the human brain. ANN models contain layers of simple computing nodes that operate as nonlinear summing devices. These nodes are richly interconnected by weighted connection lines, and the weights are adjusted when data are presented to the network during a "training" process. Successful training can result in artificial neural networks that perform tasks such as predicting an output value, classifying an object, approximating a function, recognizing a pattern in multifactorial data, and completing a known pattern [1] [2].

The objective of this paper is to provide a preliminary understanding of ANNs and answer why and when these computational tools are needed, how they are used and their possible applications inside food industry and giving as example the field of the olive grove and olive oil industry. A field of olive oil which is undergoing a constant technological evolution.

\section{Similarities between Biological Neural Networks (BNN) and Artificial Neural Networks (ANN)}

\subsection{Biological Neuron}

The human nervous system consists of billions of neurons of various types and lengths relevant to their location in the body. Every neuron shares many characteristics with other cells of the human body but it has particular and special properties to receive process and transmit an electric signal through all the interconnections of the brain communication system [3]. Some neurons are connected with receivers or effectors and others are connected to transmit and process information. The area of connection is called a synapse and binds the axon of a neuron with dendrites of the adjacent as shown in Figure 1.

The information is transmitted from one neuron to another. This information is transmitted in the form of impulses through the dendrites. Impulses tend to excite the cell. When the excitation accumulated exceeds a threshold value, the neurons send a signal through the axon to other neurons. The majority of the ANN models present the basic operation of the neuron [4].

\subsection{Artificial Neuron}

Artificial neurons are models that attempt to simulate the behavior of biological neurons. Each neuron is represented by processing unit that forms a part of one greater entity: the neural network. In general, each neuron sends its output to others by its axon and the axon takes information through potential differences or waves of power, which depends on the potential of the neuron. The input signals are produced by its synapse, adding all excitatory influences [ANN simulates it by positive weights and inhibit by negative weights]. If positive

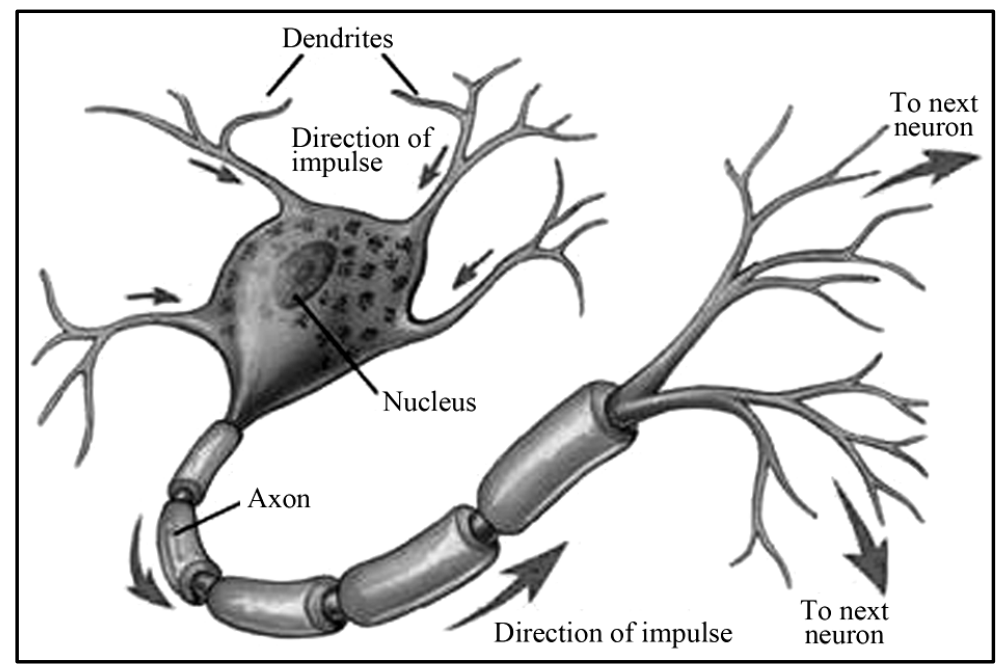

Figure 1. Structure ofa biological neuron. To can compare the performance of artificial neural it must know the structure of a biological neuron [4]. 
excitatory influences dominate, the neuron gives a positive signal and sends this message to other neurons by its output synapse. According to Figure 2, this unit of process (artificial neuron) consists of a series of entries Xi $\left(\mathrm{x}_{1}, \mathrm{x}_{2}, \ldots \mathrm{x}_{\mathrm{n}}\right)$, which are equivalent to the dendrites where they receive information in the form of stimulation. The weights that exist in the synapses Wi are equivalent in biological neuron to transmit mechanisms. The union of these values (Xi and $\mathrm{Wi}$ ) equals the inhibitory and excitatory chemical signals that occur in the synapses and to induce neuron to change their behavior. These values are the gateway of the network weighting function that converts these values in potential.

This potential is equivalent to the total number of signals that arrive on a neuron in the biological neuron by their dendrites. The weighting function is a weighted sum of the inputs and the synaptic weights. The output of weighting function comes from the activation function that transforms this value into another form that the outputs neurons can work. The output network is evaluated in the activation function that gives rise to this neuron signal output to another neighbor. The activation function will be given by the potential of resulting that can be of different ways (Table 1). In summary, the artificial neuron behaves as a biological neuron but in a very simplified way [3].

\section{ANN: Models, Characteristics, Architecture, Learning}

\subsection{Models of Artificial Neural Networks}

In the Table 2 it can find the principal and known models of artificial neural networks.

\subsection{Characteristics of an Artificial Neural Network}

Artificial neural networks have a large number of features similar to the brain due to its constitution and its foundations, as it can be to learn from the experience [4]. The artificial neural networks are increasingly used in new technologies in various areas, and present a lot of advantages such as:

- Adaptive learning capacity consists on learning how to perform some tasks by training with illustrative examples. Neural networks are dynamic adaptive systems, due to their process units. The neurons can adjust themselves and change depending on the new conditions that appear. In fact, a neural network can generate its own weight distribution by means of learning and even after this continue learning. When designing a neural network must be given the appropriate structure for its learning and training with pattern. It is necessary to develop a good algorithm of learning that provides the network the ability to discriminate, by training with patterns.

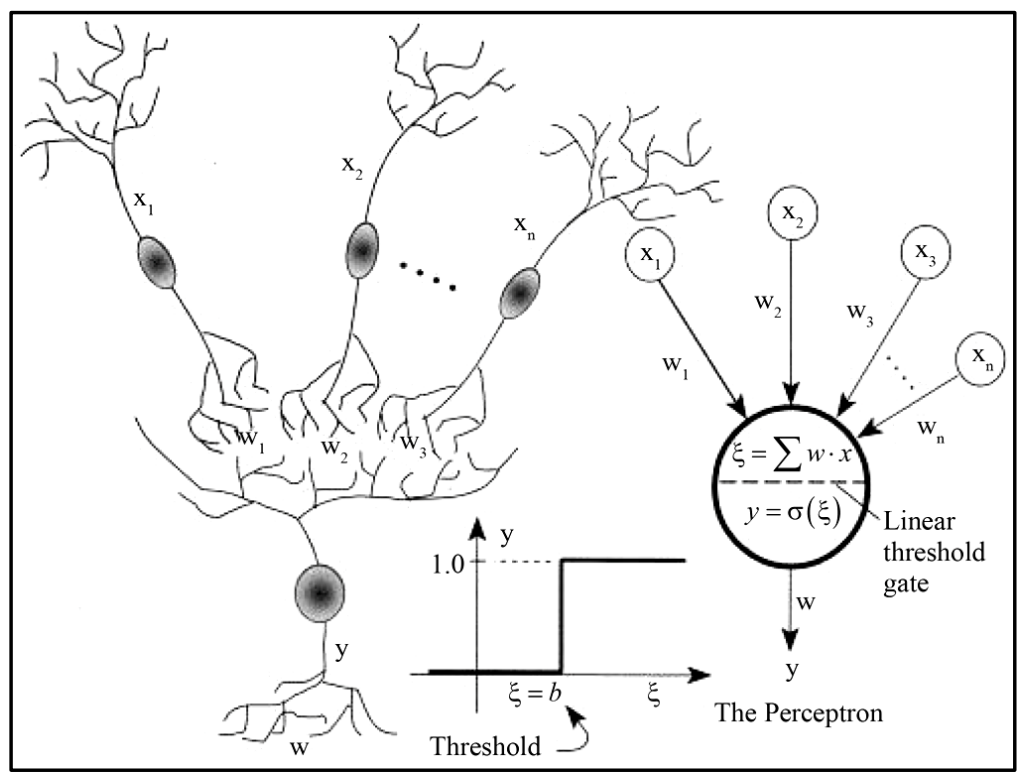

Figure 2. Similarity among a biological neuron and an artificial neuron. In this figure it can observe the difference and similarly between both neuron [4]. 
Table 1. Roles of activation of an artificial neural network. These roles are necessary can activate an ANN. According the use of which network the role will be different [4].

\begin{tabular}{|c|c|c|c|}
\hline Name & Formula & Range & Graphical \\
\hline Identity & $y=x$ & {$[-\infty,+\infty]$} & \\
\hline Unit step & $y=\operatorname{sign}(x)$ & $\{-1,+1\}$ & \\
\hline Piecewise linear & $y=\left\{\begin{array}{l}-1, \text { si } x<-l \\
x, \text { si }+l \leq x \leq-l \\
+1, \text { si } x>+l\end{array}\right.$ & {$[-1,+1]$} & \\
\hline Sigmoid & $\begin{array}{c}y=1 /\left(1+e^{\wedge}(-x)\right) \\
y=\operatorname{tgh}(x)\end{array}$ & $\begin{array}{c}{[0,+1]} \\
{[-1,+1]}\end{array}$ & \\
\hline Gaussian & $y=A \mathrm{e}^{-B x^{2}}$ & {$[0,+1]$} & \\
\hline Sinusoidal & $y=A \sin (\omega x+\varphi)$ & {$[-1,+1]$} & \\
\hline
\end{tabular}

- Self-organization. The neural networks employ their ability to adaptive learning for to autoorganize the information they receive during learning and/or the operation. In this way, neural networks are able to give an answer to a new situation, solve problems in which the input information is not very clear or incomplete.

- Tolerance to failures. Neural networks tolerate failures with respect to the data that extract or abstract the essential features of the learned entries, so they can properly process incomplete or distorted data. Furthermore, networks can continue their function (with some degradation) although destroyed part of the network. This is because the neural networks have their information distributed in the connections between neurons. These connections will have their values according to received stimuli, and an output pattern that represents the information stored that will generate.

- Operation in real time. Neural computations can be performed in parallel. Most of the networks can operate in a real-time environment, the need for change in weights connections or training is minimal.

- Easy insertion into existing technology. A network can be rapidly trained, tested, verified and transferred to a hardware implementation [5].

\subsection{Architecture of a Neural Network}

The artificial neuron is an element of simple processing that produces a single output from an inputs vector. When talk about architecture of an ANN, must be taken into account:

- Number of level or layers: the distribution of neurons in the neural network is done forming levels or layers of a determined number of nodes each one. There are input, output and hidden layers.

- Connection patterns depending on the links between the elements of the different layers. The ANN can be classified as totally connected when all the outputs from a level get to all and each one of the nodes in the following level. In this case, there will be more connections than nodes. When some links in the network are lost, the network is partially connected. 
Table 2. Summarize the well-known neural networks models (own elaboration).

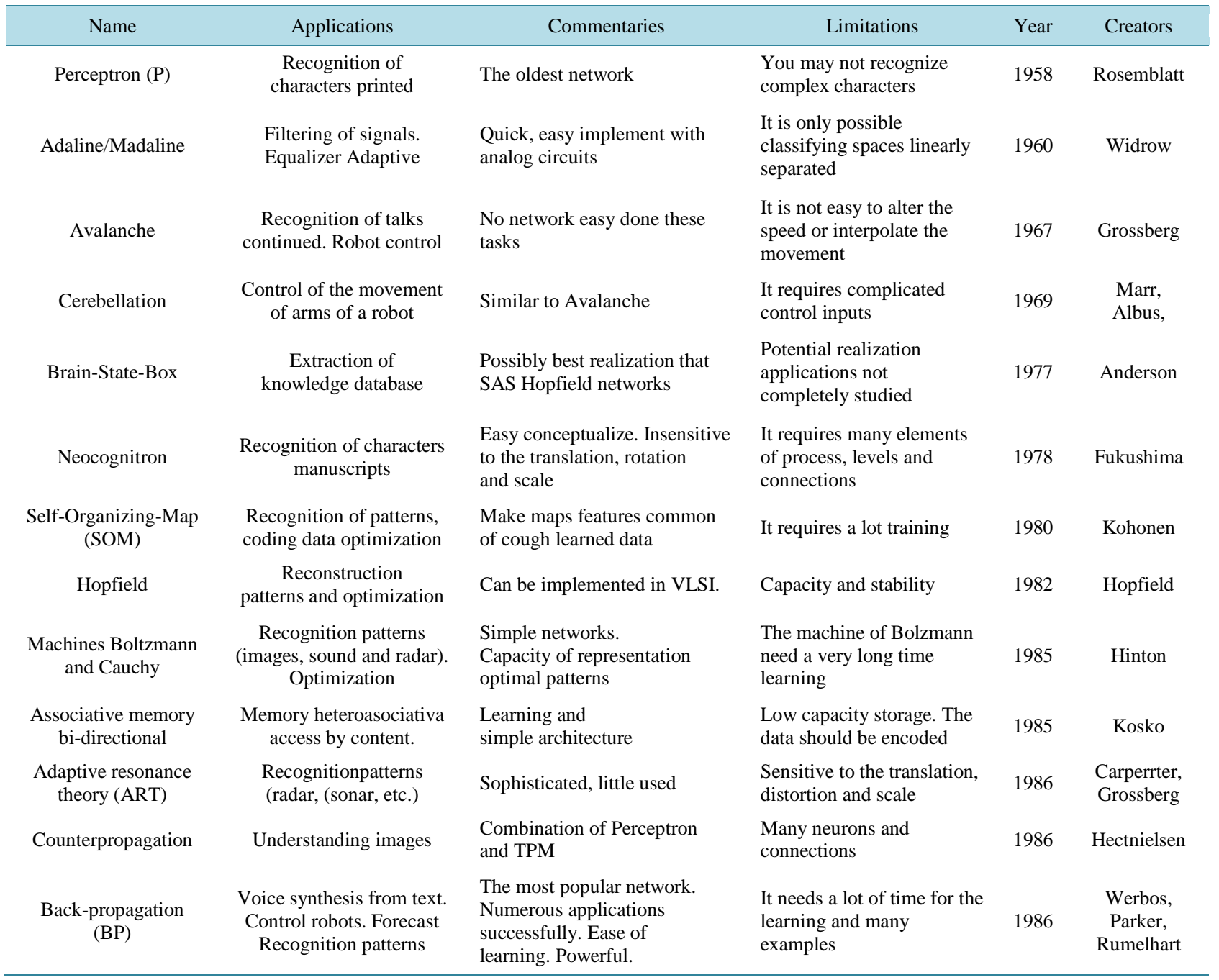

- The direction of the information flow through the layers. The connectivity between the nodes of a neural network is related with the way in which the exits of neurons are directed to become into entrances other neurons. The output signal of a node can be one of the entrances another element of process, or even be an entrance to it. When any output of the neurons is input of neurons of the same level or preceding levels, the network is described as feedforward. By the contrary, if there is at least one connected exit as entrance of neurons of previous levels or of the same level, including themselves, the network is denominated of feedback. The feedback networks that have at least a closed loop of back propagation are called recurrent.

\subsection{Process of Learning}

Learning ANN consists in determining precise values of weights for all connections, all trained for the efficient resolution of a problem. During the training session, the weights converge gradually to the values that make each entry to produce the desired output vector [3].

The end of the learning period can be determined:

- using a number fixed cycles,

- when the error falls below a preset amount,

- when the modification of the weights is irrelevant.

Depending on the scheme of learning and the problem to be solved, three types of learning schemes can be distinguished [4]: 
- Supervised learning. In the supervised knowledge the training is controlled by an external agent (supervisor, teacher), which watches the answer that the network is supposed to generate from a determined entrance. The supervisor compares the output of the network with the expected one and determines the amount of the modification to be made in the weight. The objective is to decrease the difference between the answer of the network and the desired values. For example the ANN that uses this type of learning is Adaline, MPL, BP, and Associative Memory Bi-directional.

- Unsupervised learning. The ANNs with unsupervised learning (also known as self-supervised) do not require any external element to adjust the weight of the communication links to their neurons. The main problem in the unsupervised classification is to divide the space where the objects are in groups or categories. The ANN that use this type of learning are Hopfield, Machines Boltzmann and Cauchy, networks with competitive learning, such as SOM and ART.

\section{ANN: Models, Characteristics, Architecture, Learning}

The development of a successful ANN project has to be constituted for a number of stages, as illustrated in Figure 3.

\subsection{Problem Definition and Formulation}

In the first phase, the problem has to definite. There exist engineering problems for which finding the perfect solution requires a practically impossible amount of resources and an acceptable solution would be fine. ANNs can give good solutions for such classes of problems.

\subsection{System Design}

In order to select a good NN configuration, there are several factors to take into consideration. The major points of interest regarding the ANN topology selection are related to network design, training, and practical considerations. Some of the design considerations include determining the number of input and output nodes to be used, the number of hidden layers in the network and the number of hidden nodes used in each hidden layer. The number of input nodes is typically taken to be the same as the number of state variables. The number of output nodes is typically the number that identifies the general category of the state of the system. Each node constitutes a processing element and it is connected through various weights to other elements. In order to predict with the least possible error, these values must be optimized.

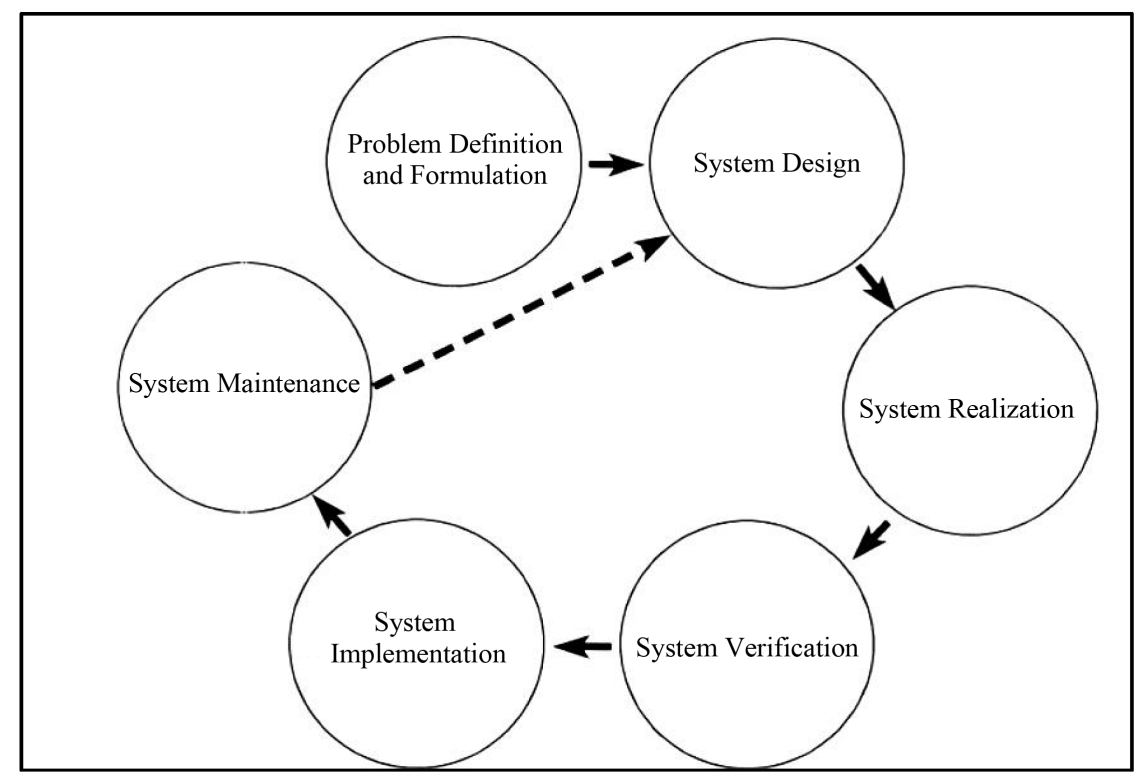

Figure 3. The various phases in an ANN development project. These stages are fundamental to right performance of ANN (own elaboration). 
The data must be enough big to cover the possible known variation in the problem domain. This database into three subsets for training-test and validation. The samples that compose the input and output must have the same format and must be normalized in the range 0 or 1 or -1 to 1 depending on the transfer function used. The initial weights of an NN play a significant role in the convergence of the training method. Knowing input data and output data and objects obtain, we can design ANN. First there was to choose to type of ANN and once defined the topology of the ANN it is required to establish algorithm that allow an adequation of the inner parameters of the network.

\subsection{System Realization}

System realization involves one of two basic steps, training/learning. In this training step, the connection parameters were adjusted with training function showed in Table 1, such that, for the given dataset the neural network-predicted output dataset matched with real output dataset. The training step is influence for various parameters (network size, learning rate, number of training cycles, acceptable error, etc.) can affect the design and error of the final network. For this, we must considered determining the input and output variables, choosing the size of the training data set, initializing network weights, choosing training parameter values (such as learning rate and momentum rate), and selecting training stopping criteria, are important for several network topologies. In function of ANN type we choose of type supervised or not supervised learning. The number of training examples used to train an ANN is sometimes critical to the success of the training process. If the number of training examples is not sufficient, then the network cannot correctly learn the actual input-output relation of the system. If the number of training examples is too large, then the network training time will be longer. For some applications, such as real-time adaptive neural control, training time is a critical.

\subsection{System Verification}

Verification is intended to confirm the capability of the ANN based model to respond accurately to examples never used in network development. This stage includes comparing the performance of ANN based model to those of other approaches. For each training function, the matrix of weight must be optimized in its respective learning process. In the verification process, the obtained data by ANN must be compared with the real ones to optimize the parameters of the ANN by statistical tools. The testing/validation process is the final stage of the work. When all ANN parameters are optimized, the validation process is only used to test them.

\subsection{System Implementation}

This phase includes embedding the obtained network in appropriate working system such as hardware controller or computer program, depending of the function have ANN, such as, optimization process or control process or predict on-line. Final testing of the integrated system should also be carried out before its release to the end user.

\subsection{System Maintenance}

This stage includes update of the medium, changes in variables, new data that influence the development of the network.

\section{Applications of Neural Networks}

The ANNs are an emerging computer technology that can be used in a large number and variety of applications such as, control, monitoring and modeling, recognition, detection an research for patterns, predicts on-line, image processing, optimization and signal processing. This applications can use in several fields as production of manufacturing, agriculture..., business, marketing, medicine, transports, energy, trade the greater, etc... In this paper, we can see some examples, what use has artificial neural network in different food industry.

\subsection{Control, Monitoring and Modeling of Industrials Processes}

At present, the industry has a number of objectives: improve of quality products, reducing of waste, elimination of toxins, and above all the increase of the benefits. The industry has also to be efficient. For this reason neural networks are implanted in control, modeling and monitoring of existing industrial processes, thus reducing costs 
process and increasing the outputs, as it can be seen at the various articles referenced in the Table 3.

\subsection{Recognition, Detection, Classification and Search for Patterns}

The ANNs are used for recognition, detection, classification and search for patterns, e.g., for classification of seeds or apples in real time through digital images, analyzing texture and color. Besides defect detection on cherries or pattern recognition of fruit shape quantitatively between others as the Table 4 incanted.

\subsection{Prediction On-Line Parameters}

Predicting the behavior of an even which depends from the time, with base in a group of values that are obtained from different moments. In food industries, the ANNs are very used, overall for predict on-line quality and characteristics of food, parameters of elaboration process, prediction temperatures for food storage. The Table 5 shows some applications of ANN in food industry and kind of ANN used.

\subsection{Image Processing}

More than 200 applications of neural networks in image processing and discuss the present and possible future role of neural networks, especially feed-forward neural networks, Kohonen feature maps and Hop1eld neural networks. The various applications are used in different industries, for example in forest industry or clothe industry to see defects of raw material and final product. In food industry, the image processing method has become very popular and indirectly used to determine the sugar content of fruits. For example, high correlation coefficients have been obtained between the sugar content and the red value in the chromatic coordinates of banana peels [59] or the application of ANN to the color grading of apples [60].

\section{Table 3. Several examples of application of control, monitoring and modelling of industrial process (own elaboration).}

\begin{tabular}{|c|c|c|c|}
\hline Sample & Object of investigation & Type of ANN & References \\
\hline \multirow[t]{4}{*}{ Food in general } & Modeling and control of a food extrusion process using ANN & $\mathrm{BP}$ & $\begin{array}{l}\text { Popescu et al., (2001) } \\
\text { [5] }\end{array}$ \\
\hline & Modeling sterilization process of canned foods ANNs & $\mathrm{BP}$ & $\begin{array}{l}\text { Gonçalves, et al., } \\
\text { (2005) [6] }\end{array}$ \\
\hline & $\begin{array}{l}\text { Prediction models and for optimization of constant } \\
\text { temperature retort (CRT) thermal processing of conduction } \\
\text { heating foods using ANN. }\end{array}$ & Non defined & $\begin{array}{l}\text { Chen, and Ramaswamy, } \\
\text { (2002) [7] }\end{array}$ \\
\hline & $\begin{array}{l}\text { Application of ANN in the modelling of the thermal treatment } \\
\text { of food }\end{array}$ & RNN, BP & $\begin{array}{l}\text { Luera Peña, Minim, } \\
\text { (2001) [8] }\end{array}$ \\
\hline Apple & ANN modeling of apple drying process. & MLPFF & $\begin{array}{l}\text { Khoshhal, et al., } \\
\text { (2010) [9] }\end{array}$ \\
\hline Apple juice & Modeling dead-end ultrafiltration of apple juice using ANN & MLPFF, BP & $\begin{array}{l}\text { Gökmen, et al., } \\
\text { (2009) [10] }\end{array}$ \\
\hline Bread & $\begin{array}{l}\text { Dynamic model of the kneading process based on ANN that } \\
\text { allows predicting the bread dough temperature and the } \\
\text { delivered power }\end{array}$ & RNN & $\begin{array}{l}\text { Lamrini, et al., (2012) } \\
\text { [11] }\end{array}$ \\
\hline Lime & $\begin{array}{l}\text { ANN modeling of mass transfer during osmotic dehydration } \\
\text { of kaffir lime peel. }\end{array}$ & MLPFF & $\begin{array}{l}\text { Lertworasirikul, Saetan, } \\
\text { (2010) [12] }\end{array}$ \\
\hline Squid protein & Modeling of squid protein hydrolysis using ANN & MLP & $\begin{array}{l}\text { Abakarov, et al., (2011) } \\
\text { [13] }\end{array}$ \\
\hline Tomato & Modeling of tomato drying using ANN & MLP & $\begin{array}{l}\text { Movagharnejad, Nikza, } \\
\text { (2007) [14] }\end{array}$ \\
\hline Viscous fluids & $\begin{array}{l}\text { Neural network modeling of end-over-end thermal processing } \\
\text { of particulates in viscous fluids }\end{array}$ & MLP BP & $\begin{array}{l}\text { Meng and Ramaswamy, } \\
\text { (2010) [15] }\end{array}$ \\
\hline Wheat & Modeling of wheat soaking using two ANNs & MLP, RBF & $\begin{array}{l}\text { Kashaninejad, (2009) } \\
{[16]}\end{array}$ \\
\hline Wine & Modeling wine characteristics using ANN & MLPFF, BP & $\begin{array}{l}\text { Vlassides, et al., } \\
\text { (2001) [17] }\end{array}$ \\
\hline
\end{tabular}


Table 4. Several examples of application of recognition, detection, classification and research for patterns (own elaboration).

\begin{tabular}{|c|c|c|c|}
\hline Sample & Object of investigation & Type of ANN & References \\
\hline \multirow[t]{3}{*}{ Apple } & Develop ANN-based apple classifier & MLP, BP & Bhatt et al., (2014) [18] \\
\hline & $\begin{array}{l}\text { Apple classification system based on machine vision and ANN, } \\
\text { which classifies apple in real time on the basis of physical } \\
\text { parameters of apple such as size, color and external defects. }\end{array}$ & MLP, BP & $\begin{array}{l}\text { Bhatt and Pant, (2013) } \\
\text { [19] }\end{array}$ \\
\hline & $\begin{array}{l}\text { Classification of apple surface features using machine } \\
\text { vision and ANN }\end{array}$ & MLPFF & Yang, (1993) [20] \\
\hline Beans & Classification of beans using computer vision system and ANNs & MLPFF & Kilic et al., (2007) [21] \\
\hline Boiled shrimp & $\begin{array}{l}\text { Classifications of boiled shrimp’s shape using image analysis } \\
\text { and ANN model. }\end{array}$ & MLP & $\begin{array}{l}\text { Poonnoy et al., (2014) } \\
\text { [22] }\end{array}$ \\
\hline Cherries & $\begin{array}{l}\text { Use of genetic artificial neural networks and spectral imaging } \\
\text { for defect detection on cherries }\end{array}$ & MLPFF, BP & $\begin{array}{l}\text { Guyer and Xiukun } \\
\text { Yang, (2000) [23] }\end{array}$ \\
\hline Food in general & $\begin{array}{l}\text { A new pattern recognition method for detecting fouling on } \\
\text { stainless steel is presented in food processing. }\end{array}$ & MLPFF, BP & $\begin{array}{l}\text { Wallhäußer et al., (2011) } \\
\text { [24] }\end{array}$ \\
\hline Fruits & Pattern recognition of fruit shape quantitatively with ANN & $\mathrm{SOM}$ & $\begin{array}{l}\text { Morimoto et al., (2000) } \\
\text { [25] }\end{array}$ \\
\hline Grape & $\begin{array}{l}\text { Determination of anthocyanin concentration in whole grape skins } \\
\text { using hyperspectral imaging and adaptive boosting ANN }\end{array}$ & MLPFF & $\begin{array}{l}\text { Fernandes et al., (2011) } \\
\text { [26] }\end{array}$ \\
\hline Lamb & $\begin{array}{l}\text { Classification according to prediction the lamb carcass grades } \\
\text { using features extracted from lamb chop images }\end{array}$ & MLP & $\begin{array}{l}\text { Chandraratne et al., } \\
\text { (2007) [27] }\end{array}$ \\
\hline Pig muscles & $\begin{array}{l}\text { Duroc and Iberian pork neural network classification by visible } \\
\text { and near infrared reflectance spectroscopy }\end{array}$ & RBF & $\begin{array}{l}\text { Del Moral. et al., } \\
\text { (2009) [28] }\end{array}$ \\
\hline $\begin{array}{l}\text { The starch of } \\
\text { potato, cassava, } \\
\text { corn }\end{array}$ & $\begin{array}{l}\text { Classify the data set and to predict mechanical properties (tensile } \\
\text { strength and strain at break of starch-based films using ANN }\end{array}$ & MLPFF & $\begin{array}{l}\text { Dieulot and Skurtys, } \\
\text { (2013) [29] }\end{array}$ \\
\hline Wine & Prediction of problematic wine fermentations using ANN & MLP, BP & $\begin{array}{l}\text { Román et al., (2011) } \\
\text { [30] }\end{array}$ \\
\hline
\end{tabular}

\subsection{Optimization}

In general, the objective in optimization is to allocate a limited amount of resources to a set of certain partial tasks such that some objective or costs function is minimized (or maximized). A great number of variables usually enter the problem, and to evaluate and minimize the objective function, a combinatorial problem has to be solved. In the Table 6 we can be observed some examples of optimization of elaboration process conditions of food or optimization of storage conditions of vegetables and fruits between others.

\subsection{Signal Processing}

From a signal processing perspective, it is imperative to develop a proper understanding of basic neural network structures and how they impact signal processing algorithms and applications. A challenge in surveying the field of neural network paradigms is to identify those neural network structures that have been successfully applied to solve real world problems from those that are still under development or have difficulty scaling up to solve realistic problems. When dealing with signal processing applications, it is critical to understand the nature of the problem formulation so that the most appropriate neural network paradigm can be applied. In addition, it is also important to assess the impact of neural networks on the performance, robustness, and cost-effectiveness of signal processing systems and develop methodologies for integrating neural networks with other signal processing algorithms. Because of the ANN are used in different fields and industries. In food industry, we can find several researches. One of all develops two-way classification models using ANN to classify the stored beef meat samples into two groups: "unspoiled" and "spoiled"; based on the microbial population as alternative to electronic noise [67].

\section{Applications in Field of the Olive Oil}

In this field, the artificial neural networks have different applications: to classify the olive fruit for their 
Table 5. Several examples of application prediction on-line parameters (own elaboration).

\begin{tabular}{|c|c|c|c|}
\hline Sample & Object of investigation & Type of ANN & References \\
\hline $\begin{array}{l}\text { Agricultural } \\
\text { products }\end{array}$ & $\begin{array}{l}\text { ANN method to predict the drying characteristics of } \\
\text { agricultural products such as hazelnut, bean and chickpea }\end{array}$ & MLPFF, BP & Topuz (2010) [31] \\
\hline Carrot & $\begin{array}{l}\text { Predicting properties of dried carrot based on composition, } \\
\text { drying technique, and microstructural features }\end{array}$ & $\mathrm{P}$ & $\begin{array}{l}\text { Kerdpiboon, et al., (2006) } \\
\text { [32] }\end{array}$ \\
\hline Cheese & $\begin{array}{l}\text { Predicting the final process time in the acidification step for } \\
\text { cheese production. }\end{array}$ & $\mathrm{P}$ & $\begin{array}{l}\text { Jun-ichiHoriuchi, et al., } \\
\text { (2004) [33] }\end{array}$ \\
\hline Chicken & $\begin{array}{l}\text { Predicting the final temperature of chicken carcasses in an } \\
\text { industrial scale using ANN }\end{array}$ & MLPFF, BP & Silveira, et al. (2014) [34] \\
\hline Chicken nuggets & $\begin{array}{l}\text { Developing a model to predict the mechanical textural } \\
\text { properties of the fried breaded chicken nuggets by using } \\
\text { image texture processing }\end{array}$ & MLPFF & Qiao et al., (2007) [35] \\
\hline Corn & Artificial neural networks to predict corn yield & MLPFF, BP & Uno et al., (2005) [36] \\
\hline Crackers & $\begin{array}{l}\text { Moisture content and water activity prediction of } \\
\text { semi-finished cassava crackers from drying process } \\
\text { with ANN }\end{array}$ & MLPFF & $\begin{array}{l}\text { Lertworasirikul and } \\
\text { Tipsuwan, (2008) [37] }\end{array}$ \\
\hline $\begin{array}{l}\text { Fresh outcrop } \\
\text { milk cream }\end{array}$ & $\begin{array}{l}\text { Discriminating season of production and feeding regimen of } \\
\text { butters based on infrared spectroscopy and ANN }\end{array}$ & MLP & Gori et al., (2012) [38] \\
\hline \multirow[t]{3}{*}{ Food in general } & $\begin{array}{l}\text { Predicting of cold spot temperature in retort sterilization of } \\
\text { starch-based foods }\end{array}$ & $\mathrm{BP}$ & Llave et al., (2012) [39] \\
\hline & $\begin{array}{l}\text { Predicting the internal texture characteristics from } \\
\text { extrusion food surface images with ANN }\end{array}$ & MLPFF, BP & Fan et al., (2013) [40] \\
\hline & $\begin{array}{l}\text { Predicting of thermal conductivity of food as a function of } \\
\text { moisture content, temperature and apparent porosity. }\end{array}$ & MLPFF, BP & $\begin{array}{l}\text { Sablani, and Rahman, (2003) } \\
\text { [41] }\end{array}$ \\
\hline Grain & $\begin{array}{l}\text { Predicting the moisture content of grain drying } \\
\text { process using genetic algorithm }\end{array}$ & $\mathrm{BP}, \mathrm{RBF}$ & Liu, et al., (2007) [42] \\
\hline Ice cream & Predicting total acceptance of ice cream using ANN & MLPFF & $\begin{array}{l}\text { Bahramparvar, et al., (2013) } \\
\text { [43] }\end{array}$ \\
\hline Meal of beef & $\begin{array}{l}\text { Predicting shrinkage of ellipsoid beef joints as affected by } \\
\text { water immersion cooking using image analysis and ANN }\end{array}$ & $\mathrm{BP}$ & Zheng et al., (2007) [44] \\
\hline Molasses vinegar & $\begin{array}{l}\text { Prediction by ANN of the physicochemical quality of cane } \\
\text { molasses vinegar by time-temperature effect of food to flash } \\
\text { evaporator-distiller }\end{array}$ & MLPFF, BP & $\begin{array}{l}\text { Vásquez and Lescano, } \\
\text { (2010) [45] }\end{array}$ \\
\hline Oils & $\begin{array}{l}\text { ANN as an alternative to other methods utilized to determine } \\
\text { the fatty acid composition of oils. }\end{array}$ & MLPFF & Yalcin et al., (2012) [46] \\
\hline Orange juice & $\begin{array}{l}\text { Predicting physical properties of orange juice powder as well } \\
\text { as process parameters in spray dryers. }\end{array}$ & MLPFF & Chegini et al., (2008) [47] \\
\hline Orange, peach, pear & $\begin{array}{l}\text { Predicting of viscosity of fruit juice as a function of } \\
\text { concentration and temperature. }\end{array}$ & MLP & Rai et al., (2005) [48] \\
\hline Peas & Predicting maturity index peas with ANN & MLP & Higginsa et al., (2010) [49] \\
\hline Peppers & $\begin{array}{l}\text { Predicting of storage quality of fresh-cut green peppers } \\
\text { using ANN }\end{array}$ & MLPFF, BP & Meng, et al., (2012) [50] \\
\hline $\begin{array}{l}\text { Processing food } \\
\quad \text { in general }\end{array}$ & $\begin{array}{l}\text { Predicting process parameters involved in thermal/pressure } \\
\text { food processing using ANN }\end{array}$ & $\mathrm{BP}$ & Torrecilla et al., (2004) [51] \\
\hline Plum juice & $\begin{array}{l}\text { Predicting the permeate flux of red plum juice during mem- } \\
\text { brane clarification }\end{array}$ & MLPFF & $\begin{array}{l}\text { Nourbakhsh et al., (2014) } \\
\text { [52] }\end{array}$ \\
\hline Seeds & $\begin{array}{l}\text { Predicting deoxynivalenol accumulation in barley seeds } \\
\text { contaminated with Fusariumculmorum under } \\
\text { different conditions }\end{array}$ & MLP, RBF & Mateo et al., (2011) [53] \\
\hline
\end{tabular}




\begin{tabular}{|c|c|c|c|}
\hline \multicolumn{4}{|l|}{ Continued } \\
\hline $\begin{array}{l}\text { Viscous } \\
\text { non-Newtonian } \\
\text { fluid food }\end{array}$ & $\begin{array}{l}\text { Apply the ANN to predict the pressure gradients in tube flow } \\
\text { of viscous non-Newtonian fluid foods. }\end{array}$ & $\mathrm{BP}$ & $\begin{array}{l}\text { Adhikari and Jindal (2000) } \\
\text { [54] }\end{array}$ \\
\hline \multirow[t]{2}{*}{ Wheat flour } & $\begin{array}{l}\text { Predicting the correlation between farinographic properties } \\
\text { of wheat flour dough and its chemical composition }\end{array}$ & MLPFF & $\begin{array}{l}\text { Razmi-Rad et al., (2007) } \\
\text { [55] }\end{array}$ \\
\hline & $\begin{array}{l}\text { Prediction of extensograph properties of wheat-flour } \\
\text { dough: ANN }\end{array}$ & MLPFF & Abbasi et al., (2012) [56] \\
\hline Wine & Predicting the sensorial qualities of wines & SOM & Curvelo et al., (2010) [57] \\
\hline Yacon & $\begin{array}{l}\text { Prediction by ANN of the diffusivity, mass, moisture, } \\
\text { volume and solids on osmotically dehydrated yacon }\end{array}$ & MLPFF, BP & $\begin{array}{l}\text { Rojas and Vásquez, (2012) } \\
\text { [58] }\end{array}$ \\
\hline Sample & Object of investigation & Type of ANN & References \\
\hline Corn germ & Modeling syrup production process from defatted corn germ & MLPFF BP & $\begin{array}{l}\text { Millán and Gil, } \\
\text { (2011) [61] }\end{array}$ \\
\hline Food in general & Design and optimize high-pressure food processes & MLPFF BP & $\begin{array}{l}\text { Torrecilla et al., (2005), } \\
\text { (2007) [62] [63] }\end{array}$ \\
\hline Foodstuffs & $\begin{array}{l}\text { Optimization the operating conditions on heat and mass } \\
\text { transfer during foodstuffs drying }\end{array}$ & MLPFF & Hernández, (2009) [64] \\
\hline \multirow[t]{2}{*}{ Fruit } & $\begin{array}{l}\text { Optimization of heat treatment for fruit during storage } \\
\text { using ANN }\end{array}$ & MLPFF & $\begin{array}{l}\text { Morimoto et al., } \\
\text { (1997) [65] }\end{array}$ \\
\hline & Realizing the optimal control of the fruit-storage process. & MLPFF & $\begin{array}{l}\text { Morimoto et al., } \\
\text { (1997) [66] }\end{array}$ \\
\hline
\end{tabular}

processing, to test the ripeness of fruit, to detect frauds or adulterations in the olive oils or to predict the characteristic of olive oil obtained and to optimize the extraction process of olive oil.

For example, ANN was employed to fruit classification according to olive cultivar, as a tool to guarantee varietal authenticity. In this study, six olive cultivars of Trás-os-Montes region were collected in different groves and during four crop years. Ten biometrical parameters were measured and used for the linear discriminant analysis (LDA) and ANN classification model development. In this work, single MPLFF classification networks, trained using a supervised learning algorithm was used. The MLP methodology demonstrated to be a practical and effective tool for olive cultivar classification, showing high global sensitivity and specificity, even for unknown samples ( $76 \%$ and $78 \%$ for the validation data set, respectively). With this work between others, the olive oil producers can use to prevent possible olive oil adulterations with olives of non-allowed cultivars, according to the Protected Designation of Origin (DPO) or monovarietal olive oil's official regulation [68].

Other investigation described a novel method for rapid, automatic and objective prediction of the ripening index of an olive lot [69]. The method used integrates a Machine Vision system, capable of performing a color-based raw prediction of ripening index, with an ANN based algorithm to refine it. Such a refinement was based on a set of chemical parameters (oil content, sugar content and phenol content) which were provided as input to the ANN and which can be obtained by historical curves for the region where the ripening index needs to be predicted. The training of ANN was carried out using rule based on the gradient descent BP algorithm with an adaptive learning rate. For other part, FFBP with Levenberg-Marquardt algorithm is used by Ram et al., (2010) to predict the quantity oil together with model linear regressions (MLR). Both based on quality features derived from known image processing algorithms [70]. The ANNs were more accurate than linear regression, resulting in average linear correlations for two varieties of olives.

Due to the most recent changes in purchasing behavior of consumers are markedly affected by the increasing consumer's interest in a reliable geographical declaration of foods. As regards virgin olive oils, this information is deemed an additional warranty of their quality, authenticity, typicality and safety. For this purpose, GarciaGonzalez D. et al., (2009) proposed a new methodology based on MLP, a form of ANN that has been applied to the main series of compounds analyzed in oils to identify the geographical origin of virgin olive oil for this time [71]. This work made a classification function of country, region, province and PDO. Torrecilla et al., (2013) 
joined to classification of extra virgin olive oils (EVOO) used ANN. This classification was made inside PDO with its owns olive oils. For this purpose, they used as input several parameters, such as, acidity, peroxide index, $\mathrm{K}_{232}, \mathrm{~K}_{270}, \Delta \mathrm{K}$, moisture and volatile compounds. With this research we can observed the capability of supervised ANN models with smaller topologies to classify very similar EVOO samples, also these techniques can be applied to detect adulterations [72]. These researchers used a self-organizing map (SOM) to classify the aforementioned UV-vis signals from pure EVOO and adulterated samples with different additives and signals of pure EVOO with addition of two different types of noises. This can be a tool to detect adulterations although it still requires an optimization. This type of ANN was used by Marini et al., (2007) together with a MLPFF [73]. Zupan et al., (1994) already used ANN to classify olive oils. The classification was performed on analysis of eight fatty acids of Italian olive oils. In this research, BP and Kohonen were compared with prediction approximated 95\% [74].

ANNs also have other function inside olive oil field, such as, inside extraction process of olive oil. Furferi et al., 2007, 2008, development artificial neural network to predict of the two parameters: acidity level and peroxides of olive oil extracted by a continuous extraction process. Thus, allowing a real-time control of oil quality during the extraction process. BP was used on two different neural network referring to a 3 phases and 2 phases decanting technology which results obtained were acceptable [75] [76].

On the other hand, ANNs are an adequate tool to estimate the concentration of phenolic compounds, a pollutant with a high environmental impact in olive oil mill wastewater, without any previous phenological knowledge [77]. The type of ANN used in this work is a BP with feed-forward connections between neurons or back connections with a prediction horizon and supervised learning. The ANNs developed and optimized was able to predict the caffeic acid concentration value in a waste stream from olive oil extraction. This research had important results because the difference between the real and the predicted values was about $5 \%$. In other study performed by the same investigators, an integrated artificial neural network (ANN)/laccase biosensor is designed to prediction of cathecol concentration of olive oil mill wastewater. The obtained results gave difference between the real and the predicted values less than $1 \%$ [78].

Other researchers as Bordons and Cueli in (2004) intended to find an application of a predictive controller that deals with measurable disturbances in extraction process in an olive oil mill. This research was focused on the thermal part of the process and it shown the combination of experimental results with validated results. This work didn't use ANN as tool of work but we can observe as if other researchers used this tool for elaboration process optimization [79]. This is the case of Jiménez et al., 2008, 2009 [2] [80]. In this work the authors built an ANN for real-time prediction of the moisture and fat content in olive pomace using two-phase olive oil processing. With help of AOTF-NIR system that obtained the oil spectrum from horizontal decanter and data analysis, they development an ANN based on the BPFF. These ANN's predictions can be performed quickly during the extraction process, allowing a rapid regulation of technological variables for minimal fat loss.

\section{Conclusion}

In this review the reader can introduce principal characteristics and the ANN's creation process in the ANN's world. Although the fundamental conclusion is numerous applications that ANNs have as we can observe in this review. In some field the ANNs can be used for their enormous advantages, over all for their ability to learn from examples make them efficient problem solving paradigms. Older artificial neural networks have limitations that should not be overlooked, the interest in ANN's field continues growing and optimizing better for solving, controlling or modeling all class of problems that can appear.

\section{Acknowledgements}

This work is supported by excellence project of Junta de Andalucía, "Modeling and optimization of the process of elaboration of virgin olive oil. Project” I. and it is a preliminary work of E.F.'s PhD thesis.

\section{Conflict of Interest}

The authors have declared no conflict of interest.

\section{References}

[1] Basheer, I.A. and Hajmeer, M. (2000) Artificial Neural Networks: Fundamentals, Computing, Design, and Application. 
Journal of Microbiological Methods, 43, 3-31. http://dx.doi.org/10.1016/S0167-7012(00)00201-3

[2] Jiménez, A., Aguilera, M.P., Uceda, M. and Beltrán, G. (2009) Neural Network as Tool for Virgin Olive Oil Elaboration Process Optimization. Journal of FoodEngineering, 95, 135-141. http://dx.doi.org/10.1016/j.jfoodeng.2009.04.021

[3] BasogainOlabe, X. (2005) Artificial Neural Networks and Their Applications. School of Engineering, Bilbao.

[4] Matich, D.J. (2001) Neural Networks: Basic Concepts and Applications. National University of Technology—Faculty Regional Rosario. Group of Applied Research in the Chemical Engineering (GIAIQ).

[5] Popescu, O., Popescu, D., Wilder, J. and Karwe, M. (2001) A New Approach to Modelling and Control of a Food Extrusion Process Using Artificial Neural Network and an Expert System. Journal of Food Process Engineering, 24, 1736. http://dx.doi.org/10.1111/j.1745-4530.2001.tb00529.x

[6] Gonçalves, E.C., Minim, LA., Coimbra, J.S.R. and Minim, V.P.R. (2005) Modeling Sterilization Process of Canned Foods Using Artificial Neural Networks. Chemical Engineering and Processing, 44, 1269-1276. http://dx.doi.org/10.1016/j.cep.2005.04.001

[7] Chen, C.R. and Ramaswamy, H.S. (2002) Modeling and Optimization of Constant Retort Temperature (CRT) Thermal Processing Using Coupled Neural Networks and Genetic Algorithms. Journal of Food Process Engineering, 25, 351379. http://dx.doi.org/10.1111/j.1745-4530.2002.tb00571.x

[8] Luera Peña, W.E. and Minim, L.A. (2001) Application of Neural Networks in the Modelling of the Thermal Treatment of Food. LWT-Food Science and Technology, 3, 81-88.

[9] Khoshhal, A., Dakhel, A., Etemadi, A. and Zereshk, S. (2010) Artificial Neural Network Modeling of Apple Drying Process. Journal of Food Process Engineering, 33, 298-313. http://dx.doi.org/10.1111/j.1745-4530.2009.00435.x

[10] Gökmen, V., Açar, O.C., Serpen, A. and Süğüt, I. (2009) Modeling Dead-End Ultrafiltration of Apple Juice Using Artificial Neural Network. Journal of FoodProcessEngineering, 32, 248-264. http://dx.doi.org/10.1111/j.1745-4530.2007.00214.x

[11] Lamrini, B., Della Valle, G., TreleaPerrot, I.C. and Trystram, G. (2012) A New Method for Dynamic Modeling of Bread Dough Kneading Based on Artificial Neural Network. Food Control, 26, 512-524.

[12] Lertworasirikul, S. and Saetan, S. (2010) Artificial Neural Network Modeling of Mass Transfer during Osmotic Dehydration of Kaffir Lime Peel. Journal of Food Engineering, 98, 214-223.

[13] Abakarov, A., Teixeira, A., Simpson, R., Pinto, M. and Almonaci, S. (2011) Modeling of Squid Protein Hydrolysis: Artificial Neural Network Approach. Journal of Food Process Engineering, 34, 2026-2046. http://dx.doi.org/10.1111/j.1745-4530.2009.00567.x

[14] Movagharnejad, K. and Nikzad, M. (2007) Modeling of Tomato Drying Using Artificial Neural Network. Computers and Electronics in Agriculture, 59, 78-85. http://dx.doi.org/10.1016/j.compag.2007.05.003

[15] Meng, Y. and Ramaswamy, H.S. (2010) Neural Network Modeling of End-over-End Thermal Processing of Particulates in Viscous Fluids. Journal of Food Process Engineering, 33, 23-47. http://dx.doi.org/10.1111/j.1745-4530.2008.00272.x

[16] Kashaninejad, M., Dehghani, A.A. and Kashiri, M. (2009) Modeling of Wheat Soaking Using Two Artificial Neural Networks (MLP and RBF). Journal of Food Engineering, 91, 602-607. http://dx.doi.org/10.1016/j.jfoodeng.2008.10.012

[17] Vlassides, S., Ferrier, J.G. and Block, D.E. (2001) Using Historical Data for Bioprocess Optimization: Modeling Wine Characteristics Using Artificial Neural Networks and Archived Process Information. Biotechnology and Bioengineering, 73, 55-68. http://dx.doi.org/10.1002/1097-0290(20010405)73:1<55::AID-BIT1036>3.0.CO;2-5

[18] Bhat, A.K. (2014) An Analysis of the Performance of Artificial Neural Network Technique for Apple Classification. AI \& Society, 29, 103-111. http://dx.doi.org/10.1007/s00146-012-0425-z

[19] Bhatt, A.K. and Pant, D. (2013) Automatic Apple Grading Model Development Based on Back Propagation Neural Network and Machine Vision, and Its Performance Evaluation. AI \& Society, 30, 45-56.

[20] Yang, Q. (1993) Classification of Apple Surface Features Using Machine Vision and Neural Networks. Computers and Electronics in Agriculture, 9, 1-12. http://dx.doi.org/10.1016/0168-1699(93)90025-V

[21] Kılıç, K., Boyaci, H.I., Koecsel, H. and Kuesmenoglu, I. (2007) A Classification System for Beans Using Computer Vision System and Artificial Neural Networks. Journal of Food Engineering, 78, 897-904. http://dx.doi.org/10.1016/j.jfoodeng.2005.11.030

[22] Poonnoy, P., Yodkeaw, P., Sriwai, A., Umongkol, P. and Intamoon, S. (2014) Classification of Boiled Shrimp’s Shape Using Image Analysis and Artificial Neural Network Model. Journal of Food Process Engineering, 37, 257-263.

[23] Guyer, D. and Yang, X. (2000) Use of Genetic Artificial Neural Networks and Spectral Imaging for Defect Detection on Cherries. Computers and Electronics in Agriculture, 29, 179-194. http://dx.doi.org/10.1016/S0168-1699(00)00146-0 
[24] Wallhäußer, E., Hussein, W.B., Hussein, M.A., Hinrichs, J. and Becker, T.M. (2011) On the Usage of Acoustic Properties Combined with an Artificial Neural Network-A New Approach of Determining Presence of Dairy Fouling. Journal of Food Engineering, 103, 449-456. http://dx.doi.org/10.1016/j.jfoodeng.2010.11.015

[25] Morimoto, T., Takeuchi, T., Miyata, H. and Hashimoto, Y. (2000) Pattern Recognition of Fruit Shape Based on the Concept of Chaos and Neural Networks. Computers and Electronics in Agriculture, 26, 171-186. http://dx.doi.org/10.1016/S0168-1699(00)00070-3

[26] Fernandes, A.M., Oliveira, P., Moura, J.P., Oliveira, A.A., Falco, V., Correia, M.J. and Melo-Pinto, P. (2011) Determination of Anthocyanin Concentration in Whole Grape Skins Using Hyperspectral Imaging and Adaptive Boosting Neural Networks. Journal of Food Engineering, 105, 216-226. http://dx.doi.org/10.1016/j.jfoodeng.2011.02.018

[27] Chandraratne, M.R., Kulasiri, D. and Samarasinghe, S. (2007) Classification of Lamb Carcass Using Machine Vision: Comparison of Statistical and Neural Network Analyses. Journal of Food Engineering, 82, 26-34. http://dx.doi.org/10.1016/j.jfoodeng.2007.01.003

[28] Del Moral, F.G., Guillén del Moral, L.G., O’Vallea, F. and Martínez del Moral, R.G. (2009) Duroc and Iberian Pork Neural Network Classification by Visible and Near Infrared Reflectance Spectroscopy. Journal of Food Engineering, 90, 540-547. http://dx.doi.org/10.1016/j.jfoodeng.2008.07.027

[29] Dieulot, J.-Y. and Skurtys, O. (2013) Classification, Modeling and Prediction of the Mechanical Behavior of StarchBased Films. Journal of Food Engineering, 119, 188-195. http://dx.doi.org/10.1016/j.jfoodeng.2013.05.028

[30] Román, C., Hernández, O.G. and Urtubia, U.A. (2011) Prediction of Problematic Wine Fermentations Using Artificial Neural Networks. Bioprocess and Biosystem Engineering, 34, 1057-1065.

[31] Topuz, A. (2010) Predicting Moisture Content of Agricultural Products Using Artificial Neural Networks. Advances in Engineering Software, 41, 464-470. http://dx.doi.org/10.1016/j.advengsoft.2009.10.003

[32] Kerdpiboon, S., Kerr, W. and Devahastin, S. (2006) Neural Network Prediction of Physical Property Changes of Dried Carrot as a Function of Fractal Dimension and Moisture Content. Food Research International, 39, 1110-1118. http://dx.doi.org/10.1016/j.foodres.2006.07.019

[33] Horiuchi, J., Shimada, T., Funahashi, H., Tada, K., Kobayashi, M. and Kanno, T. (2004) Artificial Neural Network Model with a Culture Database for Prediction of Acidification Step in Cheese Production. Journal of Food Engineering, 63, 459-465. http://dx.doi.org/10.1016/j.jfoodeng.2003.09.005

[34] Silveira, C., Belledeli, B.D., Soares, M.B.A., Treichel, H. and Mazutti, M.A. (2014) Use of Artificial Neural Network for Industrial Prediction of Final Temperature of Chicken Carcasses. Journal of Food Process Engineering, 37, 1-9. http://dx.doi.org/10.1111/ifpe.12053

[35] Qiao, J., Wang, N., Ngadi, M.O. and Kazemi, S. (2007) Predicting Mechanical Properties of Fried Chicken Nuggets Using Image Processing and Neural Network Techniques. Journal of Food Engineering, 79, 1065-1070. http://dx.doi.org/10.1016/j.jfoodeng.2006.03.026

[36] Uno, Y., Prasher, S.O., Lacroix, R., Goel, P.K., Karimi, Y., Viau, A. and Patel, R.M. (2005) Artificial Neural Networks to Predict Corn Yield from Compact Airborne Spectrographic Imager Data. Computers and Electronics in Agriculture, 47, 149-161. http://dx.doi.org/10.1016/j.compag.2004.11.014

[37] Lertworasiriku, S. and Tipsuwan, Y. (2008) Moisture Content and Water Activity Prediction of Semi-Finished Cassava Crackers from Drying Process with Artificial Neural Network. Journal of Food Engineering, 84, 65-74. http://dx.doi.org/10.1016/j.jfoodeng.2007.04.019

[38] Gori, A., Cevoli, A., Fabbri, A., Cavoni, M.F. and Losi, G. (2012) A Rapid Method to Discriminate Season of Production and Feeding Regimen of Butters Based on Infrared Spectroscopy and Artificial Neural Networks. Journal of Food Engineering, 109, 525-530. http://dx.doi.org/10.1016/j.jfoodeng.2011.10.029

[39] Llave, Y.A., Hagiwara, T. and Sakiyama, T. (2012) Artificial Neural Network Model for Prediction of Cold Spot Temperature in Retort Sterilization of Starch-Based Foods. Journal of Food Engineering, 109, 553-560. http://dx.doi.org/10.1016/j.jfoodeng.2011.10.024

[40] Fan, F.H., Ma, Q., Ge, J., Peng, Q.Y., William, W. and Riley, T.S.Z. (2013) Prediction of Texture Characteristics from Extrusion Food Surface Images Using a Computer Vision System and Artificial Neural Networks. Journal of Food Engineering, 118, 426-433. http://dx.doi.org/10.1016/j.jfoodeng.2013.04.015

[41] Sablani, S.S. and ShafiurRahman, M. (2003) Using Neural Networks to Predict Thermal Conductivity of Food as a Function of Moisture Content, Temperature and Apparent Porosity. Food Research International, 36, 617-623. http://dx.doi.org/10.1016/S0963-9969(03)00012-7

[42] Liu, X., Chen, X., Wu, W. and Peng, G. (2007) A Neural Network for Predicting Moisture Content of Grain Drying Process Using Genetic Algorithm. Food Control, 18, 928-933. http://dx.doi.org/10.1016/j.foodcont.2006.05.010

[43] Bahramparvar, M. (2013) Predicting Total Acceptance of Ice Cream Using Artificial Neural Network. Journal of Food Processing and Preservation, 38, 1080-1088. 
[44] Zheng, C., Sun, D.W. and Zheng, L. (2007) Predicting Shrinkage of Ellipsoid Beef Joints as Affected by Water Immersion Cooking Using Image Analysis and Neural Network. Journal of Food Engineering, 79, 1243-1249. http://dx.doi.org/10.1016/j.jfoodeng.2006.04.010

[45] Vásquez, V. and Lescano, C. (2010) Prediction by Artificial Neural Networks of the Physicochemical Quality of Cane Molasses Vinegar by Time-Temperature Effect of Food to Flash Evaporator-Distiller. Scientia Agropecuaria, 1, 63-73.

[46] Yalcin, H., Toker, O.S., Ozturk, I., Dogan, M. and Kism, O. (2012) Prediction of Fatty Acid Composition of Vegetable Oils Based on Rheological Measurements Using Nonlinear Models. European Journal of Lipid Science and Technology, 114, 1217-1224. http://dx.doi.org/10.1002/ejlt.201200040

[47] Chegini, G.R., Khazaei, J., Ghobadian, B. and Goudarzi, A.M. (2008) Prediction of Process and Product Parameters in an Orange Juice Spray Dryer Using Artificial Neural Networks. Journal of Food Engineering, 84, 534-543. http://dx.doi.org/10.1016/j.jfoodeng.2007.06.007

[48] Rai, P., Majumdar, G.C., DasGupta, S. and De, S. (2005) Prediction of the Viscosity of Clarified Fruit Juice Using Artificial Neural Network: A Combined Effect of Concentration and Temperature. Journal of Food Engineering, 68, 527533. http://dx.doi.org/10.1016/j.jfoodeng.2004.07.003

[49] Higginsa Di Prestwidge, A., Stirling, D. and Yost, J. (2010) Forecasting Maturity of Green Peas: An Application of Neural Networks. Computers and Electronics in Agriculture, 70, 151-156. http://dx.doi.org/10.1016/j.compag.2009.09.018

[50] Meng, X., Zhang, M. and Adhikari, B. (2012) Prediction of Storage Quality of Fresh-Cut Green Peppers Using Artificial Neural Network. International Journal of Food Science and Technology, 47, 1586-1592. http://dx.doi.org/10.1111/j.1365-2621.2012.03007.x

[51] Torrecilla, J.S., Otero, L. and Sanz, P.D. (2004) A Neural Network Approach for Thermal/Pressure Food Processing. Journal of Food Engineering, 62, 89-95. http://dx.doi.org/10.1016/S0260-8774(03)00174-2

[52] Nourbakhsh, H., Emam-Djomeh, Z., Omid, M., Mirsaeedghazi, H. and Moini, S. (2014) Prediction of Red Plum Juice Permeate Flux during Membrane Processing with ANN Optimized Using RSM. Computers and Electronics in Agriculture, 102, 1-9. http://dx.doi.org/10.1016/j.compag.2013.12.017

[53] Mateo, F., Gadea-Gironés, R., Mateo, E.M. and Jiménez, M. (2011) Multilayer Perceptron Neural Networks and Radial-Basis Function Networks as Tools to Forecast Accumulation of Deoxynivalenol in Barley Seeds Contaminated with Fusarium culmorum. Food Control, 22, 88-95. http://dx.doi.org/10.1016/j.foodcont.2010.05.013

[54] Adhikari, B. and Jindal, V.K. (2000) Artificial Neural Networks: A New Tool for Prediction of Pressure Drops of NonNewtonian Fluid Foods through Tubes. Journal of Food Engineering, 46, 43-51.

[55] Razmi-Rad, E., Ghanbarzadeh, B., Mousavi, S.M., Emam-Djomeh, Z. and Khazae, J. (2007) Prediction of Rheological Properties of Iranian Bread Dough from Chemical Composition of Wheat Flour by Using Artificial Neural Networks. Journal of Food Engineering, 81, 728-734. http://dx.doi.org/10.1016/j.jfoodeng.2007.01.009

[56] Abbasi, H., Mahdi, S., Ardabili, S., Emam-djomeh, Z., Mohammadifar, M., Zekri, M. and Aghagholizadeh, A. (2012) Prediction of Extensograph Properties of Wheat-Flour Dough: Artificial Neural Networks and a Genetic Algorithm Approach. Journal of Texture Studies, 43, 326-337. http://dx.doi.org/10.1111/j.1745-4603.2011.00342.x

[57] Curvelo, J.C., Dias, G., Rrodrigues de souza, R. and Tambourgi, E. (2010) Applying of Neural Network on the Wine Sensorial Analysis from Barbados Cherry. Journal of Food Process Engineering, 33, 365-378. http://dx.doi.org/10.1111/j.1745-4530.2009.00521.x

[58] Rojas Naccha, J. and Vásquez Villalobos, V. (2012) Prediction by Artificial Neural Networks (ANN) of the Diffusivity, Mass, Moisture, Volume and Solids on Osmotically Dehydrated Yacon (Smallantus sonchifolius). Scientia Agropecuaria, 3, 201-214.

[59] Nakano, K., Kurata, K. and Kaneko, M. (1991) Effects of Alcohol Treatment on Banana Ripening and Application of Image Processing to Colour Grade Measuring. Journal Society Agriculture Structure, 21, 203-208.

[60] Nakano, K. (1997) Application of Neural Networks to the Color Grading of Apples. Computers and Electronics in Agriculture, 18, 105-116. http://dx.doi.org/10.1016/S0168-1699(97)00023-9

[61] Millán, F. and Gil, L. (2011) Design and Optimization of an Artificial Neural Network for Modeling Syrup Production Process from Defatted Corn Germ. Annals of the Metropolitan University, 11, 177-190.

[62] Torrecilla, J.S., Otero, L. and Sanz, P.D. (2005) Artificial Neural Networks: A Promising Tool to Design and Optimize High-Pressure Food Processes. Journal of Food Engineering, 69, 299-306. http://dx.doi.org/10.1016/j.jfoodeng.2004.08.020

[63] Torrecilla, J.S., Otero, L. and Sanz, P.D. (2007) Optimization of an Artificial Neural Network for Thermal/Pressure Food Processing: Evaluation of Training Algorithms. Computers and Electronics in Agriculture, 56, 101-110. http://dx.doi.org/10.1016/j.compag.2007.01.005 
[64] Hernández, J.A. (2009) Optimum Operating Conditions for Heat and Mass Transfer in Foodstuffs Drying by Means of Neural Network Inverse. Food Control, 20, 435-438. http://dx.doi.org/10.1016/j.foodcont.2008.07.005

[65] Morimoto, T., De Baerdemaeker, J. and Hashimoto, Y. (1997) Optimization of Heat Treatment for Fruit during Storage Using Neural Networks and Genetic Algorithms. Computers and Electronics in Agriculture, 19, 87-101. http://dx.doi.org/10.1016/S0168-1699(97)00037-9

[66] Morimoto, T., De Baerdemaeker, J. and Hashimoto, Y. (1997) An Intelligent Approach for Optimal Control of FruitStorage Process Using Neural Networks and Genetic Algorithms. Computers and Electronics in Agriculture, 18, 205224. http://dx.doi.org/10.1016/S0168-1699(97)00030-6

[67] Balasubramania, S., Panigrahi, S., Loguec, C.M., Gub, H. and Marchello, M. (2009) Neural Networks-Integrated Metal Oxide-Based Artificial Olfactory System for Meat Spoilage Identification. Journal of Food Engineering, 91, 91-98. http://dx.doi.org/10.1016/j.jfoodeng.2008.08.008

[68] Peres, A.M., Baptista, P., Malheiro, R., Dias, L.G., Bento, A. and Pereira, J.A. (2011) Chemometric Classification of Several Olive Cultivars from Trás-os-Montes Region (Northeast of Portugal) Using Artificial Neural Networks. Chemometrics and Intelligent Laboratory Systems, 105, 65-73. http://dx.doi.org/10.1016/j.chemolab.2010.11.001

[69] Furferi, R., Carfagni, M. and Daou, M. (2008) Real-Time Estimation of Olive Oil Quality Parameters: A Combined Approach Based on ANNs and Machine Vision. New Aspects of Computers Part: II. Proceedings of the 12th WSEAS International Conference on Computers, Iraklion, 23-25 July 2008, 387-392.

[70] Ram, T., Wiesman, Z., Parmet, I. and Edan, Y. (2010) Olive Oil Content Prediction Models Based on Image Processing. Biosystems Engineering, 105, 221-232. http://dx.doi.org/10.1016/j.biosystemseng.2009.10.011

[71] García-González, D.L., Luna, G., Morales, M.T. and Aparicio, R. (2009) Stepwise Geographical Traceability of Virgin Olive Oils by Chemical Profiles Using Artificial Neural Network Models. European Journal of Lipid Science and Technology, 111, 1003-1013. http://dx.doi.org/10.1002/ejlt.200900015

[72] Torrecilla, J.S., Cancilla, J., Matute, G. and Díaz Rodríguez, P. (2013) Neural Network Models to Classify Olive Oils within the Protected Denomination of Origin Framework. International Journal of Food Science and Technology, 48, 2528-2534. http://dx.doi.org/10.1111/ijfs.12245

[73] Marini, F., Magrí, A.L., Bucci, R. and Magrí, A.D. (2007) Use of Different Artificial Neural Networks to Resolve Binary Blends of Monocultivar Italian Olive Oils. Analytica Chimica Acta, 599, 232-240. http://dx.doi.org/10.1016/j.aca.2007.08.006

[74] Zupan, J., Novic, M., Li, X. and Gasteiger, J. (1994) Classification of Multicomponent Analytical Data of Olive Oils Using Different Neural Networks. Analytica Chimica Acta, 292, 219-234. http://dx.doi.org/10.1016/0003-2670(94)00085-9

[75] Furferi, R., Carfagni, M. and Daou, M. (2007) Artificial Neural Network Software for Real Time Estimation of Olive Oil Qualitative Parameters during Continuous Extraction. Computers and Electronics in Agriculture, 55, 115-131. http://dx.doi.org/10.1016/j.compag.2006.12.006

[76] Furferi, R., Carfagni, M. and Daou, M. (2008) Real-Time Estimation of Peroxides and Acidity Level of Extra-Virgin Olive Oil: An Integrated Approach. International Journal of Mathematics and Computers in Simulation, 2, 206-214.

[77] Torrecilla, J.S., Mena, M.L., Yáñez-Sedeño, P. and García, J. (2007) Application of Artificial Neural Network to the Determination of Phenolic Compounds in Olive Oil Mill Wastewater. Journal of Food Engineering, 81, 544-552. http://dx.doi.org/10.1016/j.jfoodeng.2006.12.003

[78] Torrecilla, J.S., Mena, M.L., Yáñez-Sedeño, P. and García, J. (2008) Field Determination of Phenolic Compounds in Olive Oil Mill Wastewater by Artificial Neural Network. Biochemical Engineering Journal, 38, 171-179. http://dx.doi.org/10.1016/j.bej.2007.06.013

[79] Bordons, C. and Cueli, J. (2004) Predictive Controller with Estimation of Measurable Disturbances. Application to an Olive Oil Mill. Journal of Process Control, 14, 305-315. http://dx.doi.org/10.1016/S0959-1524(03)00043-X

[80] Jiménez, A., Beltrán, G., Aguilera, M.P. and Uceda, M. (2008) A Sensor-Software Based on Artificial Neural Network for the Optimization of the Olive Oil Elaboration Process. Sensors and Actuators B: Chemical, 129, 985-990. http://dx.doi.org/10.1016/j.snb.2007.09.030

\section{Abbreviations}

MLP: Multilayer Perceptron; BP: Backpropagation; MLPFF: Multilayer Feedforward; RBF: Radian Backpropagation; SOM: Self-Organizing-Map; RNN: Radian neural network; P: Perceptron. 
Scientific Research Publishing (SCIRP) is one of the largest Open Access journal publishers. It is currently publishing more than 200 open access, online, peer-reviewed journals covering a wide range of academic disciplines. SCIRP serves the worldwide academic communities and contributes to the progress and application of science with its publication.

Other selected journals from SCIRP are listed as below. Submit your manuscript to us via either submit@scirp.org or Online Submission Portal.
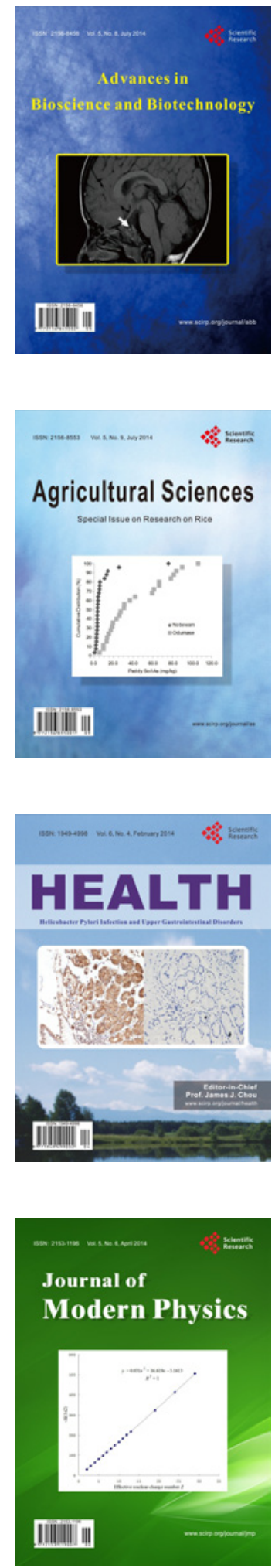
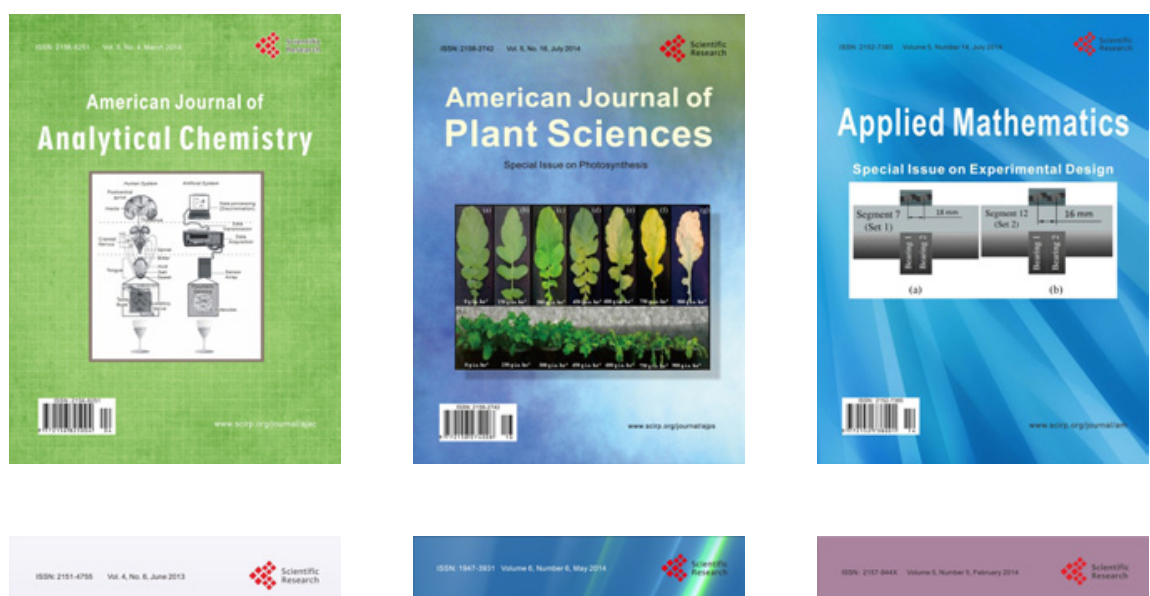

Creative Education
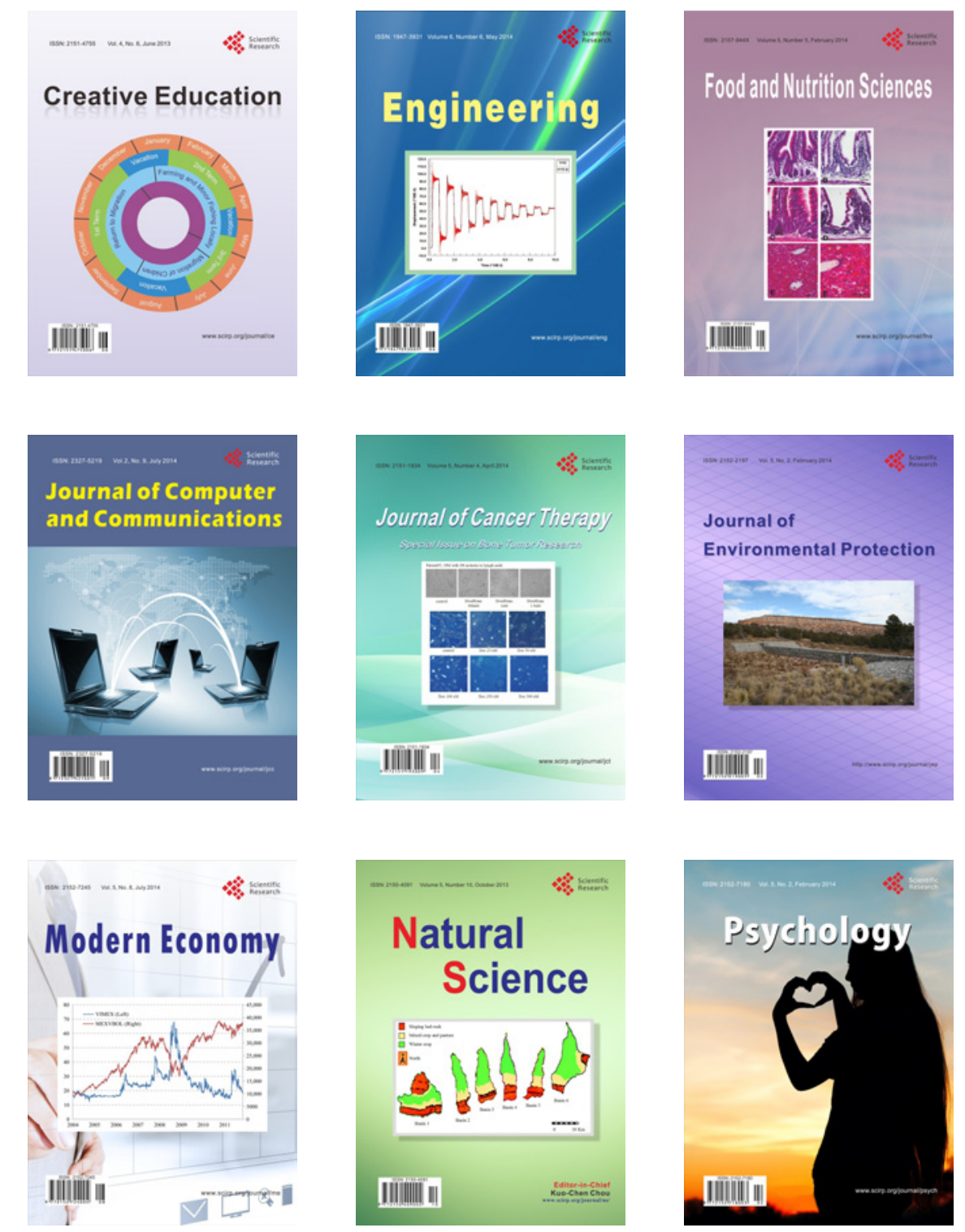